\title{
Structure and dynamics of a woody plant community of a tropical semi-deciduous seasonal forest in the "Estação Ecológica do Panga", municipality of Uberlândia, Minas Gerais, Brazil
}

\author{
LUCIANA VIEIRA DE PAIVA ${ }^{1}$, GLEIN MONTEIRO DE ARAÚJO' ${ }^{2,4}$ and \\ FERNANDO PEDRONI ${ }^{3}$
}

(received: May 5, 2005; accepted: June 21, 2007)

\begin{abstract}
Structure and dynamics of a woody plant community of a tropical semi-deciduous seasonal forest in the "Estação Ecológica do Panga", municipality of Uberlândia, Minas Gerais, Brazil.). Studies of plant community dynamics are essential in understanding the demographic patterns of species since changes in demographic rates can affect the floristic composition and future structure. The purpose of the present study was to analyze the changes in the community structure and floristic composition of woody plants in a tropical semi-deciduous forest in Uberlândia in central Brazil, during a 10-years period. The data were collected in 1989 and in 2000 in 50 quadrats $(10 \mathrm{~m} \mathrm{x} 10 \mathrm{~m})$ where all trees with a minimum circumference at breast height of $10 \mathrm{~cm}$ were sampled. In 1989, 93 species and 1103 individuals were registered. Over a period of 10 years, seven new species were added to the community, although eight disappeared. The main change that occurred during this period in the floristic composition was the replacement of savannah species occurring in forest gaps by those from the forest understory.
\end{abstract}

Key words - growth, mortality, recruitment, tropical forest

RESUMO - (Estrutura e dinâmica da comunidade arbórea de uma floresta semi-decídua na Estação Ecológica do Panga, Uberlândia, Minas Gerais, Brasil). Estudos de dinâmica de comunidades vegetais são essenciais para o entendimento dos padrões demográficos das espécies, uma vez que as mudanças nas taxas demográficas da comunidade podem afetar a composição florística e a estrutura futura das florestas. Portanto, o presente estudo teve por objetivo analisar as mudanças na composição florística e estrutura fitofisionômica da comunidade arbórea de uma floresta tropical semi-decídua em Uberlândia no Brasil central, durante um período de 10 anos. O trabalho foi realizado em 50 parcelas de $10 \mathrm{~m}$ x $10 \mathrm{~m}$, onde amostraram-se todas as árvores com circunferência a altura do peito com mínimo de $10 \mathrm{~cm}$ em 1989 e novamente em 2000. Em 1989 registrou-se um total de 93 espécies e 1103 indivíduos, enquanto que em 2000, 92 espécies e 1107 indivíduos. Em 10 anos houve a perda de oito espécies e recrutamento de sete. A principal mudança que ocorreu na composição florística nesse período foi a substituição de espécies de savana, que ocorriam nas clareiras, por aquelas de sub-bosque da comunidade florestal.

Palavras-chave - crescimento, floresta tropical, mortalidade, recrutamento

\section{Introduction}

Tropical forests have been seriously altered during the last centuries, through selective deforestation, agricultural activities, construction of dams, progress of urban areas and constructions of highways (OliveiraFilho et al. 1997, Whitmore 1997). The anthropogenic disturbance processes have been happening on an unprecedented time scale in the ecological and geological history of these forests, causing profound changes on these ecosystems (Primack 1993) modifying their structure and dynamics (Caswell \& Cohen 1991).

\footnotetext{
1. Universidade de Brasília, Departamento de Ecologia, Pósgraduação em Ecologia, 70910-900 Brasília, DF, Brasil.

2. Universidade Federal de Uberlândia, Instituto de Biologia, Campus Umuarama, 38400-902 Uberlândia, MG, Brasil.

3. Universidade Federal de Mato Grosso, Departamento de Ciências Biológicas e da Saúde, 78698000 Pontal do Araguaia, MT, Brasil.

4._Corresponding author: glein@ufu.br
}

The modifications caused by anthropogenic disturbance have motivated the establishment of conservation programs for these ecosystems (Laurance \& Bierregaard 1997), as well as stimulated studies on community structure and dynamics in the altered environments.

The dynamics of plant communities is influenced by growth, mortality and recruitment of individuals (Lieberman et al. 1985), which could be correlated with several environmental factors that affect the distribution and structure of plant populations (Aquino et al. 1999). Such studies are carried out accompanying the changes that occur in the plant community, using permanent plots, for long periods (Swaine \& Lieberman 1987).

Most of the studies on community dynamics of Neotropical forests are reported from preserved or slightly disturbed areas; several studies were carried out in the Amazonian region (Rankin-de-Merona et al. 1990), Federal District (Felfili 1995a) and southern Minas 
Gerais (Oliveira-Filho et al. 1997). In the Triângulo Mineiro, studies were carried out on the dynamics of plant populations (Aquino et al. 1999, Schiavini et al. 2001). However, there are no published reports on dynamics of plant communities in this region.

Studies on forest community dynamics seek to understand the changes in the floristic composition, tree density and basal area, and other characteristics (Korning \& Balslev 1994, Bormann \& Berlyn 1981), fundamental for the recovery of tropical forests that undergo disturbances and for the implantation of management programs (Hartshorn 1990). Studies on community dynamics indicated that the forests are in a state of dynamic equilibrium. In spite of the fluctuations in the mortality and recruitment rates of some populations, the communities tend towards stability (Felfili 1995a). Investigations of forest dynamics can provide a basis to predict long term general changes in plant communities.

The principal objective of the present study was to analyze the changes that occurred over a 10 -year period (1989-2000) in the species composition and physiognomic structure of a tropical semi-deciduous seasonal forest in Uberlândia, central Brazil, mainly in the number of individuals and basal area, to determine current community conservation status.

\section{Material and methods}

Study area, climate and soil of the region - The study was carried out in a semi-deciduous seasonal forest, according to Veloso et al. (1991) classification, at the "Estação Ecológica do Panga" (EEP) owned by the "Universidade Federal de Uberlândia". The reserve covers an area of 410 ha located in the southern section of the Uberlândia municipal district, $35 \mathrm{~km}$ from city downtown (19 $\left.{ }^{\circ} 10^{\prime} \mathrm{Se} 48^{\circ} 23^{\prime} \mathrm{W}\right)$. All main cerrado physignomies are found in the reserve (Schiavini \& Araújo 1989).

The semi-deciduous forest studied has approximately 15 ha and is adjacent to a cerradão (a forest formation) and a gallery forest. It underwent a selective cutting in the early 1960s. In 1990, during the recovery phase, it presented Lithraea molleoides with highest importance value (Araújo \& Haridasan 1997). This species, considered to be a heliophyte by Longhi (1987), possibly occupied the area when the forest had smaller canopy covering. At present the forest has a canopy covering of more than $80 \%$ and trees up to $15 \mathrm{~m}$ high.

The climate of the area is of the tropical savanna type, with dry winter and rainy summer, with average temperature of the coldest month greater than $18^{\circ} \mathrm{C}$. The annual rainfall varies from 1,400 to $1,700 \mathrm{~mm}$; and the average maximum temperatures from $27^{\circ} \mathrm{C}$ to $30^{\circ} \mathrm{C}$ (Rosa et al. 1991).

The predominant soil of the area is Acric Red Latosol ("Latossolo Vermelho ácrico") - according to the Brazilian system of soil classification, with low organic matter content and exchangeable bases. The soils of the region originated from the Adamantina formation, Bauru group that prevail in the Uberlândia municipal district (Lima \& Bernardino 1992). Successive inventories (1989-2000) - The first inventory (T1) was carried out from August to October 1989. In one ha of the forest, 50 plots of $10 \mathrm{~m} \times 10 \mathrm{~m}$ were randomly positioned, all trees with a minimum circumference at breast height $(\mathrm{CBH})$ of $10 \mathrm{~cm}$ were tagged with aluminum labels. The circumference of the stem was measured at $1.30 \mathrm{~m}$ or, in forked individuals, below the first live branch. The results of this first inventory are published in Araújo \& Haridasan (1997).

The second sampling (T2) was carried out from January to March 2000, following the same procedure of the first survey. The perceptibly old individuals and those that did not present labels (embodied or expelled) were marked again. The individuals that were recruited (I), the ones that were not marked in T1, also received labels and were measured and identified. The trees that were not found, even after a thorough search, were considered dead.

Variables of arboreal community dynamics - the variables of the community dynamics were obtained for the period between 1989 and 2000, corresponding to 10 years and five months. The number of dead individuals $(\mathrm{M})$; the number of recruits (I); the total basal area lost (BAL) (determined by the basal area of the dead individuals); and the basal area gained (BAa), determined by the sum of the basal area of the recruits (BAr) plus the growth of the surviving individuals (BAs) were calculated.

These parameters were used to calculate the mortality and half-life, recruitment and time of duplication, the increase in population and replacement and stability.

Mortality - the annual mortality rate (Me) was calculated using an exponential model, following the recommendations of Swaine \& Lieberman (1987), according to the equation: $M e=-\left\{\operatorname{Ln}\left[(N 1-M) N^{-1}\right]\right\} \Delta t^{-1}$, in which: $N 1=$ number of individuals in the first sampling; $M=$ number of dead individuals and $\Delta \mathrm{t}=$ time interval (in years) between the samplings.

Half-life - taking as starting point the value of the mortality rate, the "half-life $\mathrm{T}(1 / 2)$ " was calculated; in other words, the time necessary for the community to reduce the number of individuals by half, considering that the present mortality rate is maintained: $T(1 / 2)=\operatorname{Ln}(0.5) M e^{-1}$.

Recruitment - the annual recruitment rate of the community (Ic), was estimated according to Sheil \& May (1996): $I c=\left\{\left(N 2 \Delta t^{-1}\right)-\operatorname{Ln}\left[1-\left(I N 2^{-1}\right)\right]\right\} N 2^{-1}$, in which $N 2=$ number of individuals in second sampling; $I=$ number of recruited individuals (for basal area this value was substituted by $\mathrm{ABg}$ ). Duplication time - duplication time (T2) was calculated from the recruiting rate, the time required for the number of individuals in the community to double if the same rate of recruiting is maintained. This calculation followed the model adapted by Korning \& Balslev (1994), where $T 2=\operatorname{Ln}(2) \operatorname{Ln}(1+I c)^{-1}$. Replacement and stability - to calculate the replacement $(\mathrm{R})$ and stability values, the model suggested by Korning \& Balslev (1994) was used, in which: $R=(T(1 / 2)+T 2) 2^{-1}$ and $E=|T(1 / 2)-T 2|$ 
Increment of community individuals - the increment (r) indicates the increase in the number of individuals in the community over the year, and it was determined using the following equation: $r=\left[\operatorname{Ln}\left(N 2 N 1^{-1}\right)\right] \Delta t^{-1}$

To test the relationship between the mortality rates and the individuals size, estimates of the dynamic parameters were made for different diameter classes, with intervals of $5 \mathrm{~cm}$ (from 3 to $58 \mathrm{~cm}$ ).

The t-test (Zar 1999) was used to test the difference between Shannon diversity indices obtained in 1998 and 2000.

\section{Results}

Ninety-three species and 1,103 individuals were sampled in T1 and 92 species and 1,107 individuals in $\mathrm{T} 2$ (table 1). During the interval between T1 and T2 (10 years and five months), there was a change of $16.13 \%$ in the specific composition due to the loss of eight species: Agonandra brasiliensis, Apeiba tibourbou, Byrsonima basiloba, Cardiopetalum calophylllum, Caryocar brasiliense, Eugenia moraviana, Guapira cacerensis and Senna sylvestris (table 2) and the recruitment of seven: Phyllanthus acuminatus, Piper arboreum, Siparuna guianensis, Tabebuia impetiginosa, Trichilia catigua, Trichilia pallida and Unonopsis lindmanii (table 2). The diversity indices of Shannon did not vary among T1 (3.72 nats ind $\left.{ }^{-1}\right)$ and T2 (3.73 nats ind ${ }^{-1}$ ).

In the period between the two inventories there was a $34.2 \%$ death toll among the 1,103 individuals marked initially, with an annual mortality rate of $4.01 \%$ (table 1 ). The species that contributed most to the mortality rate were Lithraea molleoides, followed by Alibertia sessilis, Campomanesia velutina, Chrysophyllum marginatum and Myrcia rostrata (table 2). The mortality rate was strongly influenced by the diameter classes. Trees with smaller diameters, mainly from 3 to $8 \mathrm{~cm}$, presented larger mortality rate (figure 1a).

The loss of $59.7 \%$ in basal area (table 1) was represented by individuals belonging to the first three diameter classes (figure 1b). The species that contributed most to this reduction were Lithraea molleoides, Campomanesia velutina and Ocotea pulchella (table 2).

The community presented a recruitment rate of $34.4 \%$ of the total number of individuals in the second inventory. The annual recruitment rate obtained for this study was of $4.04 \%$ (table 1 ). The majority of the recruited individuals $(95.3 \%)$ belonged to the first diameter class (figure 1c), with an annual recruitment rate of $7.21 \%$. The species that had the greatest number
Table 1. The dynamics of the arboreal community in the semideciduous forest of EEP, in the municipality of Uberlândia, State of Minas Gerais, Brazil, during a 10-year period (1989-2000).

\begin{tabular}{lcccc}
\hline & $\begin{array}{c}\text { Number of } \\
\text { individuals }\end{array}$ & $\%$ & Year & $\begin{array}{r}\text { Basal } \\
\text { area } \\
\left(\mathrm{m}^{2}\right)\end{array}$ \\
\hline $\begin{array}{l}\text { Sampling } \\
\text { time 1 (1989) }\end{array}$ & 1103 & - & - & 11.89 \\
$\begin{array}{l}\text { Sampling } \\
\text { time 2(2000) }\end{array}$ & 1107 & - & - & 12.64 \\
$\begin{array}{l}\text { Death } \\
\text { Recruitment }\end{array}$ & 377 & - & - & 2.91 \\
$\begin{array}{l}\text { Increase in } \\
\text { basal area }\end{array}$ & - & - & - & 0.71 \\
$\quad$ Mortality rate & - & 4.01 & - & 0.027 \\
$\begin{array}{l}\text { Growth rate } \\
\text { Half life }\end{array}$ & - & 4.04 & - & 0.033 \\
Doubling time & - & - & 17.27 & 25.78 \\
Reposition & - & - & 17.52 & 21.54 \\
Stability & - & - & 17.40 & 23.66 \\
\hline
\end{tabular}

of recruited individuals in the community were Alibertia sessilis, Bauhinia ungulata, Faramea cyanea, and Erytrhoxylum subracemosum (table 2), which occupy preferentially the lower canopy in the forest.

In the investigated period $0.71 \mathrm{~m}^{2}$ of the total basal area increase was due to the contribution of recruitment and $2.94 \mathrm{~m}^{2}$ due to the growth of surviving individuals (table 1). The growth in basal area in the intermediate classes (figure 1d) was due mainly to the growth of the surviving individuals of Anadenanthera colubrina and Terminalia brasiliensis which occupy the upper strata of the forest.

In terms of number of individuals, the annual recruitment was almost equal to the annual mortality observed in the community. As a consequence, the values of half-life, duplication time and basal area were very similar. The replacement time was greater in terms of basal area and the stability values were low for number of individuals and basal area, respectively (table 1).

In the two surveys, a larger number of individuals was observed in the smaller diameter classes, resulting in a frequency distribution in the form of inverted $\mathrm{J}$ (figure 1e).

The distribution of basal area in the different diameter classes was more similar in the second survey (figure 1f). The species that contributed most to the increment in recruited individuals were Alibertia sessilis and Matayba elaeagnoides and, among the survivors, Anadenanthera colubrina, Terminalia brasiliensis, Hymenaea courbaril and Terminalia phaeocarpa (table 2). 
A
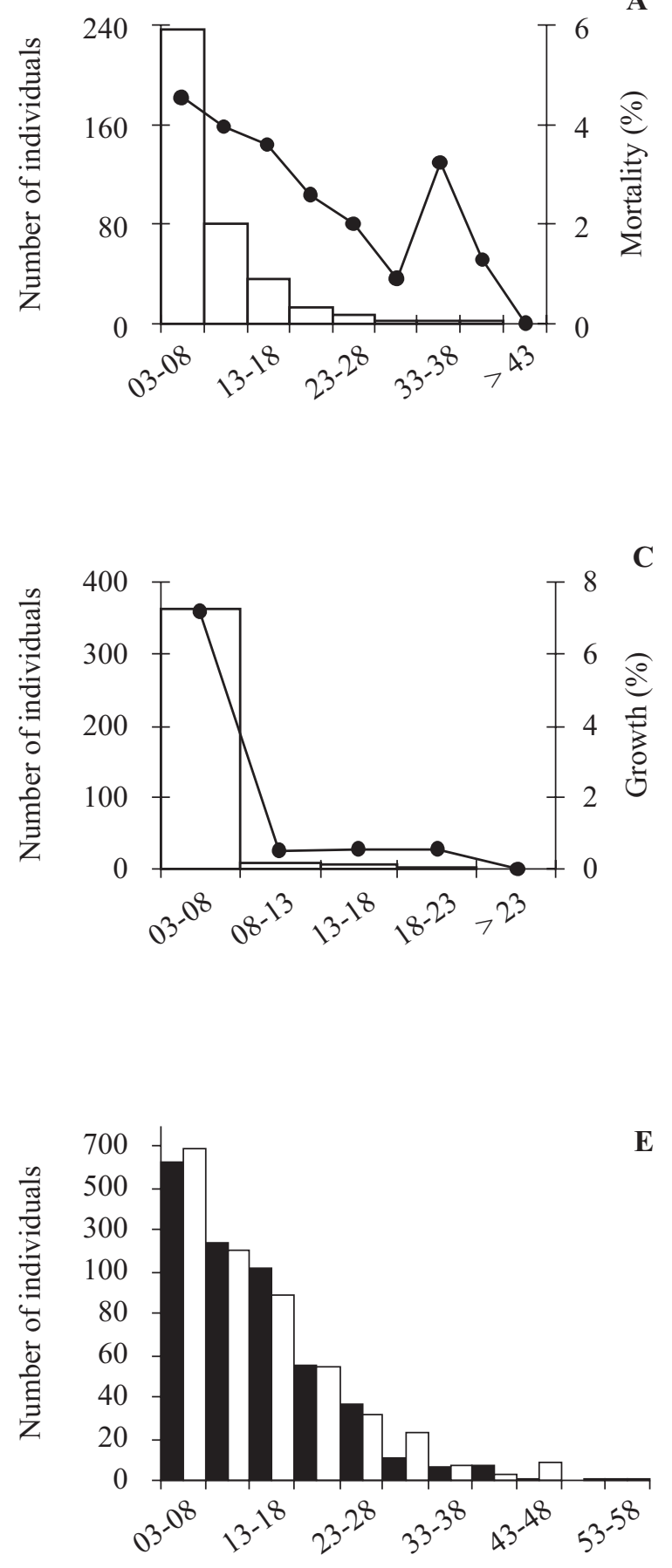

Diameter $(\mathrm{cm})$

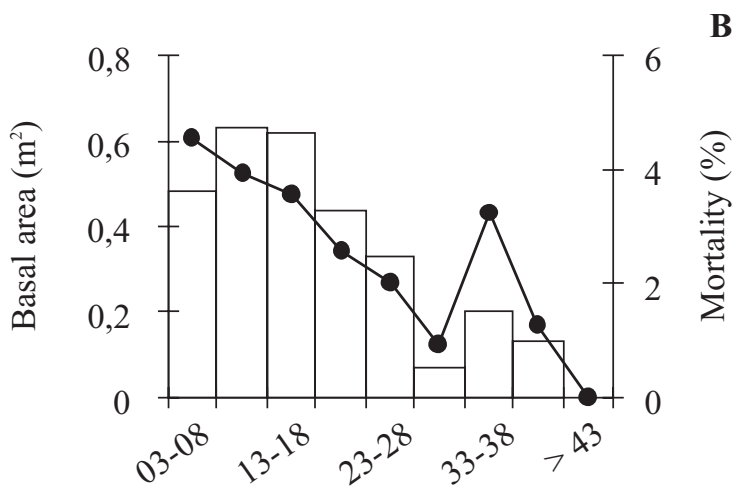

B

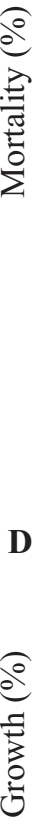
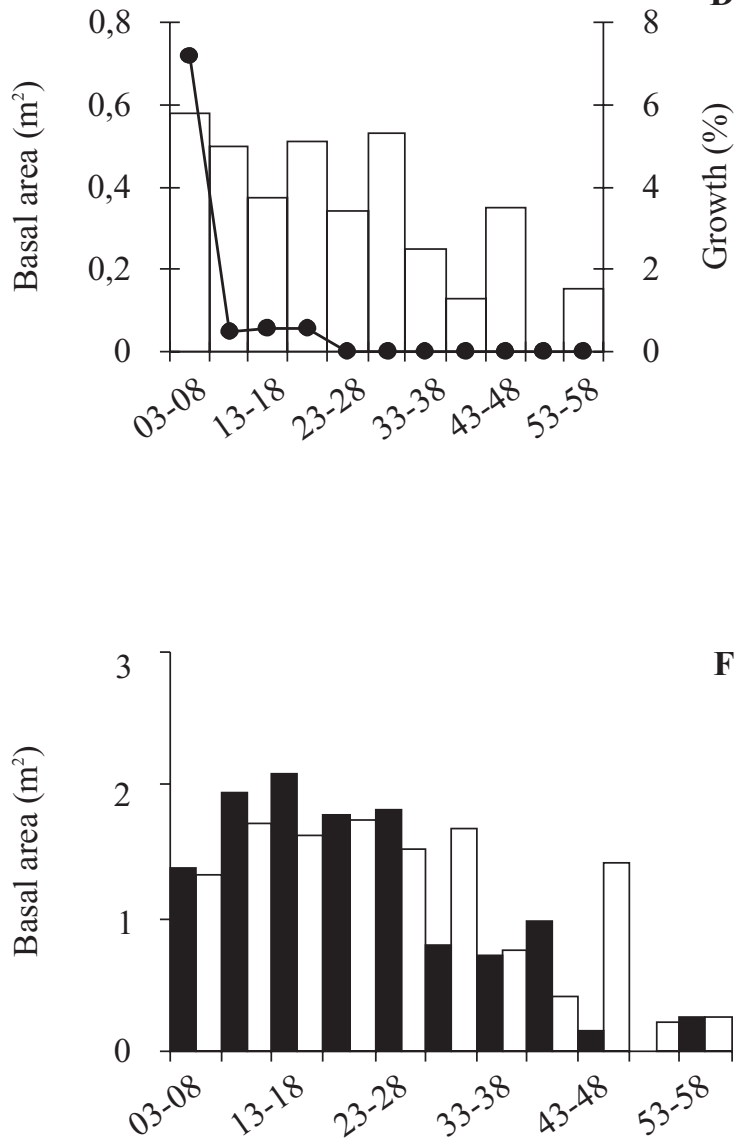

Diameter $(\mathrm{cm})$

Figura 1. Changes in the community structure and floristic composition of woody plants in different diameter classes, in a tropical semi-deciduous forest of EEP, in the municipality of Uberlândia, in the State of Minas Gerais, Brazil, during a 10-year period (1989-2000). A. Mortality rate of individuals ( $\square=$ dead individuals; $-\bullet-=$ mortality rate). B. Basal area lost $(\square=$ lost basal area; - $\bullet-=$ mortality rate). C. Number of recruited individuals $(\square=$ increase in individuals $-\bullet-=$ growth rate). D. Increase in basal area ( $\square=$ increase; $-\bullet-=$ growth rate). E. Number of individuals $(\square=$ T1 (1989); $\square=$ T2 (2000). The scale for number of individuals changes above $n=100$. F. Basal area $(\square=\mathrm{T} 1$ (1989); $\square=\mathrm{T} 2$ (2000). 
Table 2. Structure and dynamics of the tree community of a semi-deciduous forest at EEP in the municipality of Uberlândia in the State of Minas Gerais, Brazil during a 10-year period (1989-2000) in terms of number of individuals and basal area. Number of individuals: $\mathrm{N1}=$ initial (1989); Nd = Mortality; $\mathrm{Nr}=$ recruitment; N2 = final (2000); Basal area: BA1 = initial (1989); BAL = loss; $\mathrm{BAr}=$ recruitment; $\mathrm{BAa}=$ Addition; BA2 = final (2000). Species ordered by initial number of individuals (N1).

\begin{tabular}{|c|c|c|c|c|c|c|c|c|c|}
\hline \multirow[t]{2}{*}{ Species } & \multicolumn{4}{|c|}{ Number of trees } & \multicolumn{5}{|c|}{ Basal área $\left(\mathrm{m}^{2}\right)$} \\
\hline & $\mathrm{N} 1$ & $\mathrm{Nd}$ & $\mathrm{Nr}$ & $\mathrm{N} 2$ & BA1 & BAL & $\mathrm{BAr}$ & BAa & $\mathrm{BA} 2$ \\
\hline Alibertia sessilis (Vell.) K. Schum. & 109 & 41 & 116 & 184 & 0.25 & 0.11 & 0.16 & 0.24 & 0.38 \\
\hline Campomanesia velutina (Camb.) O. Berg & 83 & 35 & 5 & 53 & 0.80 & 0.31 & 0.01 & 0.03 & 0.52 \\
\hline Chrysophyllum marginatum (Hook. \& Arn.) & 82 & 29 & 1 & 54 & 0.94 & 0.18 & 0.00 & 0.10 & 0.86 \\
\hline Lithrea molleoides (Vell.) Engl. & 65 & 47 & 0 & 18 & 1.32 & 0.70 & 0.00 & 0.08 & 0.70 \\
\hline Diospyros hispida A. DC. & 59 & 16 & 5 & 48 & 0.36 & 0.04 & 0.01 & 0.10 & 0.43 \\
\hline Matayba guianensis Aubl. & 34 & 13 & 12 & 33 & 0.17 & 0.06 & 0.01 & 0.03 & 0.14 \\
\hline Bauhinia ungulata $\mathrm{L}$. & 33 & 20 & 25 & 38 & 0.05 & 0.03 & 0.03 & 0.04 & 0.06 \\
\hline Guazuma ulmifolia Lam. & 32 & 17 & 2 & 17 & 0.29 & 0.14 & 0.00 & 0.02 & 0.18 \\
\hline Cupania vernalis Camb. & 30 & 9 & 3 & 24 & 0.15 & 0.04 & 0.01 & 0.05 & 0.16 \\
\hline Terminalia phaeocarpa Eichl. & 28 & 5 & 3 & 26 & 0.39 & 0.04 & 0.03 & 0.22 & 0.57 \\
\hline Machaerium aculeatum Raddi & 27 & 10 & 5 & 22 & 0.42 & 0.17 & 0.02 & 0.06 & 0.31 \\
\hline Styrax camporum Pohl & 27 & 11 & 2 & 18 & 0.23 & 0.04 & 0.01 & 0.13 & 0.33 \\
\hline Luehea paniculata Mart. \& Zucc. & 26 & 4 & 0 & 22 & 0.28 & 0.01 & 0.00 & 0.05 & 0.32 \\
\hline Maytenus floribunda Reiss. & 26 & 1 & 4 & 29 & 0.11 & 0.00 & 0.00 & 0.03 & 0.13 \\
\hline Rhamnidium elaeocarpum Reiss. & 25 & 6 & 9 & 28 & 0.18 & 0.06 & 0.01 & 0.00 & 0.12 \\
\hline Tapirira guianensis Aubl. & 25 & 4 & 4 & 25 & 0.32 & 0.05 & 0.00 & 0.17 & 0.44 \\
\hline Terminalia brasiliensis Raddi & 25 & 0 & 14 & 39 & 0.75 & 0.00 & 0.04 & 0.33 & 1.08 \\
\hline Matayba elaeagnoides Radlk. & 23 & 3 & 15 & 35 & 0.19 & 0.01 & 0.05 & 0.19 & 0.38 \\
\hline Anadenanthera colubrina (Vell.) Brenan & 22 & 1 & 1 & 22 & 0.67 & 0.00 & 0.00 & 0.33 & 1.00 \\
\hline Myrcia rostrata DC. & 22 & 21 & 3 & 4 & 0.07 & 0.07 & 0.01 & 0.01 & 0.01 \\
\hline Ocotea pulchella Mart. & 22 & 15 & 0 & 7 & 0.25 & 0.21 & 0.00 & 0.03 & 0.07 \\
\hline Pouteria rivicoa (Gartn. f.) Ducke & 14 & 3 & 1 & 12 & 0.24 & 0.04 & 0.00 & 0.12 & 0.32 \\
\hline Casearia mariquitensis Kunth & 13 & 9 & 0 & 4 & 0.09 & 0.05 & 0.00 & 0.00 & 0.04 \\
\hline Erythroxylum subracemosum Turcz. & 13 & 8 & 16 & 21 & 0.03 & 0.02 & 0.02 & 0.02 & 0.03 \\
\hline Nectandra cissiflora Nees & 12 & 1 & 12 & 23 & 0.06 & 0.00 & 0.02 & 0.06 & 0.12 \\
\hline Casearia sylvestris $\mathrm{Sw}$. & 11 & 1 & 8 & 18 & 0.11 & 0.00 & 0.01 & 0.03 & 0.13 \\
\hline Guettarda viburnoides Cham. \& Schltdl. & 11 & 2 & 0 & 9 & 0.21 & 0.05 & 0.00 & 0.02 & 0.18 \\
\hline Hymenaea courbaril $\mathrm{L}$. & 11 & 0 & 0 & 11 & 1.02 & 0.00 & 0.00 & 0.32 & 1.34 \\
\hline Aspidosperma parvifolium A. DC. & 9 & 1 & 0 & 8 & 0.09 & 0.00 & 0.00 & 0.03 & 0.12 \\
\hline Platypodium elegans Vog. & 9 & 1 & 1 & 9 & 0.16 & 0.03 & 0.00 & 0.11 & 0.24 \\
\hline Myrsine umbellata Mart. & 9 & 5 & 3 & 7 & 0.12 & 0.05 & 0.00 & 0.06 & 0.13 \\
\hline Albizia niopoides (Spruce ex Benth.) Burkart & 7 & 1 & 0 & 6 & 0.03 & 0.00 & 0.00 & 0.04 & 0.06 \\
\hline Aspidosperma cuspa (Kunth) Blake & 7 & 0 & 0 & 7 & 0.09 & 0.00 & 0.00 & 0.04 & 0.13 \\
\hline Casearia gossypiosperma Briq. & 7 & 0 & 1 & 8 & 0.05 & 0.00 & 0.00 & 0.03 & 0.08 \\
\hline Myrcia tomentosa (Aubl.) DC. & 7 & 1 & 3 & 9 & 0.02 & 0.00 & 0.01 & 0.01 & 0.03 \\
\hline Aspidosperma cylindrocarpon Muell. Arg. & 6 & 1 & 2 & 7 & 0.01 & 0.00 & 0.00 & 0.00 & 0.01 \\
\hline Chomelia pohliana Muell. Arg. & 6 & 4 & 3 & 5 & 0.03 & 0.02 & 0.00 & 0.01 & 0.02 \\
\hline Coutarea hexandra (Jacq.) K. Schum. & 6 & 0 & 4 & 10 & 0.04 & 0.00 & 0.02 & 0.04 & 0.08 \\
\hline Psidium sartorianum (O. Berg.) Nied. & 6 & 1 & 5 & 10 & 0.02 & 0.00 & 0.01 & 0.03 & 0.05 \\
\hline Eugenia florida DC. & 5 & 1 & 3 & 7 & 0.04 & 0.01 & 0.00 & -0.01 & 0.02 \\
\hline Symplocos platyphylla (Pohl) Benth. & 5 & 0 & 8 & 13 & 0.06 & 0.00 & 0.01 & 0.05 & 0.10 \\
\hline Astronium fraxinifolium Schott & 4 & 0 & 0 & 4 & 0.05 & 0.00 & 0.00 & 0.00 & 0.06 \\
\hline Pseudobombax tomentosum (Mart. \& Zucc.) A. Robyns & 4 & 3 & 0 & 1 & 0.01 & 0.01 & 0.00 & 0.00 & 0.00 \\
\hline Roupala brasiliensis Klotzsch & 4 & 0 & 0 & 4 & 0.10 & 0.00 & 0.00 & 0.03 & 0.13 \\
\hline Acacia glomerosa Benth. & 3 & 1 & 1 & 3 & 0.01 & 0.00 & 0.00 & 0.00 & 0.01 \\
\hline Calyptranthes widgreniana $\mathrm{O}$. Berg & 3 & 0 & 4 & 7 & 0.01 & 0.00 & 0.01 & 0.01 & 0.02 \\
\hline Senna sylvestris (Vell.) H.S. Irwin \& Barneby & 3 & 3 & 0 & 0 & 0.01 & 0.01 & 0.00 & 0.00 & 0.00 \\
\hline
\end{tabular}


continuation

\begin{tabular}{|c|c|c|c|c|c|c|c|c|c|}
\hline \multirow[t]{2}{*}{ Species } & \multicolumn{4}{|c|}{ Number of trees } & \multicolumn{5}{|c|}{ Basal área $\left(\mathrm{m}^{2}\right)$} \\
\hline & N1 & $\mathrm{Nd}$ & $\mathrm{Nr}$ & $\mathrm{N} 2$ & BA1 & BAL & $\mathrm{BAr}$ & $\mathrm{BAa}$ & BA2 \\
\hline Celtis iguanaea Sarg. & 3 & 2 & 0 & 1 & 0.01 & 0.00 & 0.00 & 0.00 & 0.01 \\
\hline Copaifera langsdorffii Desf. & 3 & 1 & 2 & 4 & 0.02 & 0.00 & 0.00 & 0.02 & 0.05 \\
\hline Coussarea hydrangeifolia (Benth.) \& Hook. f. & 3 & 0 & 4 & 7 & 0.00 & 0.00 & 0.01 & 0.01 & 0.01 \\
\hline Dimorphandra mollis (Benth.) & 3 & 1 & 0 & 2 & 0.07 & 0.02 & 0.00 & 0.01 & 0.06 \\
\hline Eriotheca candolleana (K. Schum.) A. Robyns & 3 & 1 & 3 & 5 & 0.06 & 0.04 & 0.02 & 0.03 & 0.04 \\
\hline Erythroxylum daphinites Mart. & 3 & 1 & 0 & 2 & 0.05 & 0.04 & 0.00 & 0.00 & 0.01 \\
\hline Garcinia gardneriana (Panch. \& Triana) Zappi & 3 & 1 & 0 & 2 & 0.01 & 0.00 & 0.00 & 0.01 & 0.01 \\
\hline Linociera arborea Eichl. & 3 & 1 & 2 & 4 & 0.01 & 0.00 & 0.00 & 0.00 & 0.01 \\
\hline Machaerium paraguariense Hassl. & 3 & 0 & 2 & 5 & 0.01 & 0.00 & 0.02 & 0.02 & 0.03 \\
\hline Machaerium stipitatum (DC.) Vog. & 3 & 0 & 1 & 4 & 0.01 & 0.00 & 0.00 & 0.01 & 0.02 \\
\hline Piptadenia gonoacantha (Mart.) Macbr. & 3 & 0 & 2 & 5 & 0.17 & 0.00 & 0.00 & -0.01 & 0.16 \\
\hline Rudgea viburnoides (Cham.) Muell. Arg. & 3 & 2 & 4 & 5 & 0.00 & 0.00 & 0.00 & 0.00 & 0.01 \\
\hline Sweetia fruticosa Spreng. & 3 & 1 & 3 & 5 & 0.01 & 0.00 & 0.00 & 0.01 & 0.02 \\
\hline Xylopia aromatica (Lam.) Mart. & 3 & 0 & 1 & 4 & 0.01 & 0.00 & 0.00 & 0.02 & 0.03 \\
\hline Xylosma sp. & 3 & 0 & 1 & 4 & 0.01 & 0.00 & 0.00 & 0.00 & 0.01 \\
\hline Acrocomia aculeata (Jacq.) Lodd. ex Mart. & 2 & 0 & 0 & 2 & 0.12 & 0.00 & 0.00 & -0.03 & 0.09 \\
\hline Dendropanax cuneatum (DC.) Decne \& Planch. & 2 & 0 & 0 & 2 & 0.01 & 0.00 & 0.00 & 0.01 & 0.02 \\
\hline Faramea cyanea Muell. Arg. & 2 & 0 & 23 & 25 & 0.00 & 0.00 & 0.03 & 0.03 & 0.03 \\
\hline Inga sp. & 2 & 0 & 2 & 4 & 0.04 & 0.00 & 0.00 & 0.02 & 0.07 \\
\hline Margaritaria nobilis L. f. & 2 & 0 & 1 & 3 & 0.00 & 0.00 & 0.00 & 0.00 & 0.01 \\
\hline Ocotea minarum (Nees) Mez & 2 & 1 & 3 & 4 & 0.02 & 0.01 & 0.00 & 0.01 & 0.02 \\
\hline Protium heptaphyllum (Aubl.) March. & 2 & 1 & 4 & 5 & 0.02 & 0.02 & 0.03 & 0.03 & 0.03 \\
\hline Agonandra brasiliensis Benth. \& Hook. f. & 1 & 1 & 0 & 0 & 0.01 & 0.01 & 0.00 & 0.00 & 0.00 \\
\hline Apeiba tibourbou Aubl. & 1 & 1 & 0 & 0 & 0.04 & 0.04 & 0.00 & 0.00 & 0.00 \\
\hline Aspidosperma subincanum Mart. & 1 & 0 & 0 & 1 & 0.00 & 0.00 & 0.00 & 0.00 & 0.00 \\
\hline Byrsonima basiloba A. Juss. & 1 & 1 & 0 & 0 & 0.01 & 0.01 & 0.00 & 0.00 & 0.00 \\
\hline Cardiopetalum calophyllum Schltdl. & 1 & 1 & 0 & 0 & 0.00 & 0.00 & 0.00 & 0.00 & 0.00 \\
\hline Caryocar brasiliense Camb. & 1 & 1 & 0 & 0 & 0.10 & 0.10 & 0.00 & 0.00 & 0.00 \\
\hline Cheiloclinium cognatum (Miers.) A. C. Smith & 1 & 0 & 3 & 4 & 0.00 & 0.00 & 0.00 & 0.01 & 0.01 \\
\hline Chomelia sessilis Muell. Arg. & 1 & 0 & 0 & 1 & 0.00 & 0.00 & 0.00 & 0.00 & 0.00 \\
\hline Coccoloba mollis Casar. & 1 & 0 & 0 & 1 & 0.00 & 0.00 & 0.00 & 0.00 & 0.00 \\
\hline Dilodendron bipinnatum Radlk. & 1 & 0 & 0 & 1 & 0.03 & 0.00 & 0.00 & 0.00 & 0.03 \\
\hline Diospyros inconstans (Jacq.) Griseb. & 1 & 0 & 0 & 1 & 0.00 & 0.00 & 0.00 & 0.00 & 0.01 \\
\hline Endlicheria paniculata (Spreng.) Macbr. & 1 & 0 & 0 & 1 & 0.00 & 0.00 & 0.00 & 0.00 & 0.00 \\
\hline Eugenia moraviana $\mathrm{O}$. Berg & 1 & 1 & 0 & 0 & 0.00 & 0.00 & 0.00 & 0.00 & 0.00 \\
\hline Eugenia stricta Pranch. ex Bronq. \& Griseb. & 1 & 0 & 0 & 1 & 0.00 & 0.00 & 0.00 & 0.00 & 0.00 \\
\hline Guapira cacerensis (Hoehne) Lund & 1 & 1 & 0 & 0 & 0.00 & 0.00 & 0.00 & 0.00 & 0.00 \\
\hline Guarea kunthiana A. Juss. & 1 & 1 & 1 & 1 & 0.01 & 0.01 & 0.01 & 0.01 & 0.01 \\
\hline Ocotea corymbosa (Miers) Mez & 1 & 1 & 2 & 2 & 0.02 & 0.02 & 0.03 & 0.03 & 0.03 \\
\hline Ouratea cataneifolia (DC.) Engl. & 1 & 0 & 0 & 1 & 0.00 & 0.00 & 0.00 & 0.00 & 0.01 \\
\hline Pouteria gardnerii (Mart. \& Miq.) Baehni & 1 & 0 & 0 & 1 & 0.02 & 0.00 & 0.00 & 0.01 & 0.03 \\
\hline Qualea dichotoma (Mart.) Warm. & 1 & 0 & 0 & 1 & 0.00 & 0.00 & 0.00 & 0.00 & 0.00 \\
\hline Simira viridiflora (Allem. \& Saldanha) Steyerm. & 1 & 0 & 0 & 1 & 0.01 & 0.00 & 0.00 & 0.01 & 0.03 \\
\hline Tabebuia roseo-alba (Ridley) Sandw. & 1 & 0 & 0 & 1 & 0.03 & 0.00 & 0.00 & 0.01 & 0.04 \\
\hline Virola sebifera Aubl. & 1 & 0 & 1 & 2 & 0.00 & 0.00 & 0.00 & 0.00 & 0.00 \\
\hline Vochysia tucanorum Mart. & 1 & 0 & 2 & 3 & 0.00 & 0.00 & 0.00 & 0.01 & 0.01 \\
\hline Phyllanthus acuminatus Vahl & 0 & 0 & 1 & 1 & 0.00 & 0.00 & 0.00 & 0.00 & 0.00 \\
\hline Piper arboreum Aubl. & 0 & 0 & 1 & 1 & 0.00 & 0.00 & 0.00 & 0.00 & 0.00 \\
\hline Siparuna guianensis Aubl. & 0 & 0 & 4 & 4 & 0.00 & 0.00 & 0.01 & 0.01 & 0.01 \\
\hline Tabebuia impetiginosa (Mart. ex DC.) Standl. & 0 & 0 & 1 & 1 & 0.00 & 0.00 & 0.00 & 0.00 & 0.00 \\
\hline Trichilia catigua A. Juss. & 0 & 0 & 1 & 1 & 0.00 & 0.00 & 0.00 & 0.00 & 0.00 \\
\hline Trichilia pallida $\mathrm{Sw}$. & 0 & 0 & 1 & 1 & 0.00 & 0.00 & 0.00 & 0.00 & 0.00 \\
\hline Unonopsis lindmanii R. E. Fries & 0 & 0 & 1 & 1 & 0.00 & 0.00 & 0.00 & 0.00 & 0.00 \\
\hline
\end{tabular}




\section{Discussion}

The changes observed in relation to the number of species and individuals, basal area, and diversity in the study area were low when compared with values reported for others tropical forests (Lang \& Knight 1983, Korning \& Balslev 1994, Oliveira-Filho et al. 1997). The greatest change observed was in relation to floristic composition, but the species that disappeared or were recruited were represented by just one or a few individuals. Species that were not abundant in the initial survey had a greater probability of disappearing locally, between a survey and the next one (Kellman et al. 1998, Nascimento et al. 1999), being able to reappear in a subsequent survey through migration or recruitment of individuals from the seed bank and seedlings or from the growth of young individuals that did not reach the minimum criterion for inclusion in the first survey (Pedroni 2001). The greater the time interval between the samplings, the larger the possibility of changes in floristic composition. The species that disappeared (Agonandra brasiliense, Byrsonima basiloba, Cardiopetalum calophyllum, Caryocar brasiliense and Senna sylvestris) were, in their majority, found in the forest formation of cerradão and the savanna formation of cerrado sensu stricto (Costa \& Araújo 2001). Possibly, these species occupied more open areas in the forest due to a selective cutting of trees that happened approximately 30 years ago (Araújo \& Haridasan 1997). The species sampled in T2, in general, already occurred in the understorey of the EEP forest (Araújo \& Haridasan 1997). As long as most of the species that disappeared and that were recruited had only one individual, these changes were not reflected in the Shannon diversity indices in the two inventories.

During the period of 10 years and five months, in spite of the small changes in relation to the number of individuals, the forest community was relatively dynamic as far as species richness and diversity was concerned. According to Felfili (1995a), even seemingly stable communities can be dynamic due to the fluctuation between mortality, growth and recruitment that occur over time.

The mortality rate of $4.01 \%$, found in this study, is among the highest values registered for tropical forests (Hubbel \& Foster 1990, with 3.94\% in Barro Colorado and Nascimento et al. 1999, with $4.5 \%$ in Piracicaba, SP). A high mortality rate was related by Phillips (1996) to global changes, such as an increase of $\mathrm{CO}_{2}$, and by Laurance et al. (1998) and Nascimento et al. (1999) to the effects of habitat fragmentation and microclimatic alterations. In EEP, the high rate was strongly influenced by the mortality of the Lithraea molleoides population. This species is considered to be a heliophyte (Longhi 1987) and it probably occupied the area during a period in which the forest was more open (Araújo \& Haridasan, 1997). Presently, its population has been reduced to a few young and adult individuals, suggesting that this species is less competitive in more shaded environments.

The results of the present study suggest that trees with smaller diameters ( 3 to $8 \mathrm{~cm}$ ) are more susceptible to mortality. Uhl et al. (1988) and Clark \& Clark (1992) found higher mortality among individuals of less than 10 cm diameter. According to Felfili (1995b), the greater mortality among individuals belonging to the smallest diameter classes should result from the lower competition capacity in relation to the larger trees, which occupy the upper strata.

The recruitment rate found at EEP can also be considered high, placing itself among the highest values mentioned in literature, $3.08 \%$ year $^{-1}$ for an inundated forest in Añangu in Ecuador (Korning \& Balslev 1994), $3.11 \%$ year $^{-1}$ for a seasonal forest in Lavras, Minas Gerais (Oliveira-Filho et al. 1997) and $4.48 \%$ year- $^{-1}$ for a dry forest in Barro Colorado (Hubbel \& Foster 1990). The species that contributed most to the recruitment rate were Alibertia sessilis, Bauhinia ungulata and Faramea cyanea in the lower diameter classes, which occupy preferentially, the lower canopy in the forest (Araújo \& Haridasan 1997). These species seem to have been favored by the closing of the canopy due to the growth of the surviving individuals of Anadenanthera colubrina, and Terminalia brasiliensis in the intermediate diameter classes. Individuals with larger diameter concentrate gains on live biomass, through lateral growth of the stem and canopy, and may occupy and close spaces in the upper strata (Werneck et al. 2000).

At EEP, the half-life value calculated on the basis of the number of individuals was low in relation to the values found for some forests, which varies from 30 to 106 years (Lieberman \& Lieberman 1987, Crow 1980, Uhl et al. 1988, Oliveira-Filho et al. 1997), whereas the duplication time of 17.52 years was among the lowest found in literature (Oliveira-Filho et al. 1997, 18.45 years and Hubbel \& Foster 1990, 15.82 years). According to the terminology of Halle et al. (1978), the study area presents a stable sylvigenic state, since the mortality and recruitment rates, and, consequently, those of halflife and duplication period, are approximately balanced. A community can be considered as stable in relation to its structure when the stability value approaches zero and can be highly dynamic in relation to replacement time (Korning \& Balslev 1994). 
The stability and replacement values, found in this study, indicate that the sampled arboreal community, in relation to its structure, is stable and seems to be more dynamic than other tropical forests, which were studied in relation to replacement time. The most evident change observed was in relation to its specific composition due to the disappearance of species, which are common to savannah areas, and the recruitment of forest species. These observations and those that show higher mortality of species such as Lithraea molleoides), seem to indicate that the forest community at EEP is recovering from the alterations it suffered and returning to its more typical floristic composition, close to preserved forests in the region of Uberlândia.

Acknowledgement - The first author is grateful to CNPq (Conselho Nacional de Pesquisa) for a scholarship (PIBIC) during the period of this study, to Fernanda Gomide for her help during field collections and Dr. M. Haridasan and Dr. J. Hay for suggestions on the manuscript.

\section{References}

AQUINO, F.G., OLIVEIRA, M.C., SCHIAVINI, I. \& RIBEIRO, J.F. 1999. Dinâmica de populações de Anadenanthera macrocarpa e Acacia glomerosa em mata seca semidecídua na Estação Ecológica do Panga (Uberlândia-MG). Boletim de Herbário Ezechias Paulo Heringer 4:90-102.

ARAÚJO, G.M. \& HARIDASAN, M. 1997. Estrutura fitossociológica de duas matas mesófilas semi-decíduas, em Uberlândia, Triângulo Mineiro. Naturalia 22:115-129.

BORMANN, F.H. \& BERLYN, G. (eds.). 1981. Age and growth rate of tropical trees: new directions for research. Yale University, New Haven.

CASWELL, H. \& COHEN, J.E. 1991. Communities in patchy environments; a model of disturbance, competition and heterogeneity. In Ecological heterogeneity (J. Kolosa \& S.T.A. Picket, eds.). Spring-Verlag, New York, p.97-122.

CLARK, D.A. \& CLARK, D.B. 1992. Life history diversity of canopy and emergent trees in a neotropical rain forest. Ecological Monographs 62:315-344.

COSTA, A.A. \& ARAÚJO, G.M. 2001. Comparação da vegetação arbórea de cerradão e cerrado na Reserva Vegetal do Panga, Uberlândia, Minas Gerais. Acta Botanica Brasilica 15:63-72.

CROW, T.R. 1980. A rainforest chronicle: a 30-year record of change in structure and composition at El Verde, Puerto Rico. Biotropica 12:41-55.

FELFILI, J.M. 1995a. Diversity, structure and dynamic of gallery forest in central Brazil. Vegetatio 117:1-15.

FELFILI, J.M. 1995b. Growth, recruitment and mortality in the Gama gallery forest in central Brazil over a six-year period (1985-1991). Journal of Tropical Ecology 11:67-83.
HALLÉ, F., OLDEMAN, R.A.A. \& TOMLINSON, P.B. 1978. Tropical trees and forests: an architectural analysis. Springer Verlag, Berlin.

HARTSHORN, G.S. 1990. An overview of neotropical forest dynamics. In Four neotropical rainforests (A.H. Gentry, ed.). Yale University Press, New Haven, p.585-600.

HUBBEL, S.P. \& FOSTER, R.B. 1990. Structure, dynamics and equilibrium status of old-growth forest on Barro Colorado Island. In Four neotropical rainforests (A.H. Gentry, ed.). Yale University Press, New Haven, p.522-542.

KELLMAN, M., TACKABERRY, R. \& RIGG, L. 1998. Structure and function in two tropical gallery forest communities: implications for forest conservation in fragmented systems. Journal of Applied Ecology 35:195-206.

KORNING, J. \& BALSLEV, H. 1994. Growth and mortality of trees in Amazonian tropical rain forest in Ecuador. Journal of Vegetation Science 4:77-86.

LANG, G.L. \& KNIGHT, D.H. 1983. Tree growth, mortality, recruitment, and canopy gap formation during a 10 -year period in a tropical moist forest. Ecology 64: 1075-1080.

LAURANCE, W.F. \& BIERREGAARD, R.O. (eds.). 1997. Tropical forest remnants: ecology, managements and conservation of fragmented communities. University Chicago Press, Chicago.

LAURANCE, W.F., FERREIRA, J.M., RANKIN-DEMERONA, J.M. \& LAURANCE, S.G. 1998. Rain forest fragmentation and the dynamics of Amazonian tree communities. Ecology 19:2032-2040.

LIEBERMAN, D. \& LIEBERMAN, M. 1987. Forest tree grow and dynamics at La Selva, Costa Rica (1969-1982). Journal of Tropical Ecology 3:347-358.

LIEBERMAN, D., LIEBERMAN, M., HARTSHORN, G.S. \& PERALTA, R. 1985. Growth rates and age-size relationships of tropical wet forest trees in Costa Rica. Journal of Tropical Ecology 1:97-109.

LIMA, S.C. \& BERNARDINO, A.F. 1992. Mapeamento dos Solos da Bacia do Ribeirão Panga. Sociedade \& Natureza 4:85-98.

LONGHI, S.J. 1987. Aspectos fitossociológicos de uma floresta natural de Astronium balansae Engl., no Rio Grande do Sul. Revista do Centro de Ciências Rurais de Santa Maria 17:49-71.

NASCIMENTO, H.E.M., DIAS, A.S., TABANEZ, A.A.J. \& VIANA, V.M. 1999. Estrutura e dinâmica de populações arbóreas de um fragmento de floresta estacional semidecidual na região de Piracicaba, SP. Revista Brasileira de Biologia 59:329-342.

OLIVEIRA-FILHO, A.T., MELLO, J.M. \& SCOLFORO, J.R.S. 1997. Effects of past disturbance and edges on tree community structure and dynamics within a fragment of tropical semi-deciduous forest in south-eastern Brazil over a five-year period (1987-1992). Plant Ecology 131:45-66. 
PEDRONI, F. 2001. Aspectos da estrutura e dinâmica da comunidade arbórea na Mata Atlântica de planície e encosta em Picinguaba, Ubatuba, SP. Tese de doutorado, Universidade de Campinas, Campinas.

PHILLIPS, O.L. 1996. Long-term enviromental changes in tropical forests: increasing tree turnover. Enviromental Conservation 23:235-248.

PRIMACK, R.B. 1993. Essentials of conservation biology. Sinauer Press, Massachusetts.

RANKIN-DE-MERONA, J.M., HUTCHINGS, H. \& LOVEJOY, T.E. 1990. Tree mortality and recruitment over a five-year period in undisturbed upland rainforest of the central Amazon. In Four Neotropical Rainforests (A.H. Gentry, ed.). Yale University Press, New Haven, p.573-584.

ROSA, R., LIMA, S.C. \& ASSUNÇÃO, W.L. 1991. Abordagem preliminar das condições climáticas de Uberlândia. Sociedade \& Natureza 3:91-108.

SCHIAVINI, I. \& ARAÚJO, G.M. 1989. Considerações sobre a vegetação da Reserva Ecológica do Panga (Uberlândia). Sociedade \& Natureza 1:61-66.

SCHIAVINI, I., REZENDE, J.C.F. \& AQUINO, F.G. 2001. Dinâmica de populações de espécies arbóreas em matas de galeria e mata mesófila na margem do Ribeirão do Panga, MG. In Cerrado: caracterização e recuperação de matas de galeria (J.F. Ribeiro, ed.). Embrapa, Planaltina, p.267-296.
SHEIL, D. \& MAY, R.M. 1996. Mortality and recruitment rate evaluations in heterogeneous tropical forests. Journal of Ecology 84:91-100.

SWAINE, M.D. \& LIEBERMAN, D. 1987. Note on the calculation of mortality rates. Journal of Tropical Ecology 3:2-3.

UHL, C., CLARK, K., DEZZEO, N. \& MAQUIRINO, P. 1988. Vegetation dynamics in Amazonian treefall gaps. Ecology 69:751-763.

VELOSO, H.P., RANGEL FILHO, A.L.R. \& LIMA, J.C.A 1991.Classificação da vegetação brasileira, adaptada a um sistema universal. Instituto Brasileiro de Geografia e Estatística, Rio de Janeiro.

WERNECK, M.S., FRANCESCHINELLI, E.V. \& TAMEIRÃONETO, E. 2000. Mudanças na florística e estrutura de uma floresta decídua durante um período de quatro anos (1994-1998), na região do Triângulo Mineiro, MG. Revista Brasileira de Botânica 23:401-413.

WHITMORE, T.C. 1997. Tropical forest disturbance, disappearance and species loss. In Tropical forest remnants: ecology, management and conservation of fragmented communities (W.F. Laurance \& R.O. Bierregaard, eds.). University of Chicago Press, Chicago, p.3-12.

ZAR, J. H. 1999. Biostatistical Analysis. Prentice Hall, Upper Saddle River. 